\title{
The Curious Case of post-Snowball Lipid Biomarkers
}

\author{
LENNART M. VAN MALDEGEM ${ }^{1 *}$, CHRISTIAN \\ HALLMANN $^{2}$, JOCHEN J. BROCKS ${ }^{1}$ \\ ${ }^{1}$ The Australian National University, Canberra, Australia \\ * Correspondence: Lennart.vanmaldegem@anu.edu.au \\ ${ }^{2}$ Max Planck institute for Biogeochemistry, Jena, Germany
}

Eukaryotic steroid remnants are preserved in the rock record from the mid-Neoproterozoic ( $\sim 800 \quad \mathrm{Ma})$ onwards. While Tonian sedimentary rocks preserve only cholestanes $\left(\mathrm{C}_{27}\right)$, Ediacaran deposits contain up to $89 \%$ stigmastane $\left(\mathrm{C}_{29}\right)$. This change in sterane distributions is linked to the transition of largely red algal communities to Chlorophytes and was paralleled by an increased ecological relevance of early algae $[1,2]$. Precisely timing the latter is important to understand any potential causal relationship to various aspects of the Cryogenian Snowball Earth events. In this regard, our knowledge is limited given that exceedingly few studies [3] have investigated the organic geochemical signatures of direct post-Snowball deposits.

Here we compare the biomarker record from earliest Ediacaran (i.e. directly post-Marinoan) rocks with that of rock deposited in the direct aftermath of the Sturtian glacial. While sterane distributions are equivalent between both localities-preserving predominantly $\mathrm{C}_{27}$ cholestanes-alongside minor 26alkyl steranes - the relative abundance of steranes versus bacterial derived hopanes is significantly different. Using additional Neoproterozoic reference samples, we will provide an update on the late Precambrian biomarker record and what this tells us about the rise of eukaryotic communities surrounding the Cryogenian glaciations.

\section{References}

[1] Brocks JJ, et al. (2017) Nature 548: 578-81. [2] Hoshino Y, et al. (2017) Science advances 3: 
This abstract is too long to be accepted for publication.

Please revise it so that it fits into the column on one page.

e1700887. [3] van Maldegem LM, et al. (2019) Nature Communications 10: 476. 